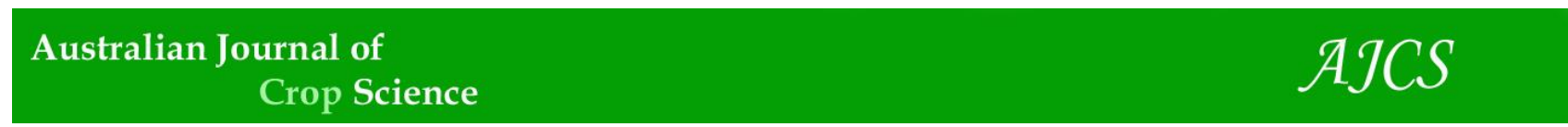

AJCS 12(04):648-654 (2018)

ISSN:1835-2707

doi: 10.21475/ajcs.18.12.04.pne1003

\title{
Analysis of phenotypic plasticity in indeterminate soybean cultivars under different row spacing
}

\author{
Alvadi Antonio Balbinot Junior ${ }^{1 *}$, Maria Cristina Neves de Oliveira ${ }^{1}$, Claudemir Zucareli ${ }^{2}$, André Sampaio \\ Ferreira ${ }^{2}$, Flávia Werner ${ }^{2}$, Marcelo Augusto de Aguiar e Silva ${ }^{2}$
}

${ }^{1}$ Embrapa Soybean, Rodovia Carlos João Strass, distrito de Warta, CEP 86001-970, Londrina, Paraná state, Brazil

${ }^{2}$ Londrina State University, Rodovia Celso Garcia Cid, PR 445, Km 380, Caixa Postal 6001, 86051-980, Londrina,

Paraná state, Brazil

*Corresponding author: alvadi.balbinot@embrapa.br

\begin{abstract}
This study aimed to evaluate how branch and stem variables contribute to grain yield per plant of two indeterminate soybean cultivars at varied row spacing. Four experiments were conducted in the 2013/14 and 2014/15 cropping seasons under a randomized complete block design with three replications. Each experiment consisted of one row spacing: $0.2 \mathrm{~m}$ (narrow row), 0.5 $\mathrm{m}$ (traditional), $0.5 \mathrm{~m}$ (crossed rows), and 0.2/0.8 m (twin rows). We evaluated two cultivars (BRS 359 RR and BMX RR Potência) and three seeding rates: 150,300 , and 450 thousand seeds ha $^{-1}$. Regarding phenotypic plasticity, grain production per plant was regarded as a dependent variable, while the number of branches per plant, the percentage of grain production from branches, and yield components of branches and stems as independent variables. Data underwent stepwise regression and principal component analysis. The results showed that number of pods per plant from branches is the most determinant variable of plasticity trait, regardless of row spacing. The number of pods per plant from branches and stems, the number of branches per plant, and the percentage of grain production from branches were associated with the plasticity. The number of grains per pod and the thousandgrain mass from branches and stems had no significant contribution to the soybean plasticity.
\end{abstract}

Keywords: Glycine max (L.) Merrill; row spacing; seeding rate; stem; branches.

Abbreviations: PROD_grain production per plant; NBPL_number of branches per plant; NPPLB_number of pods per plant from branches; NPPLS_number of pods per plant from stems; NGPB_number of grains per pod from branches; NGPS_number of grains per pod from stems; TGMB_thousand-grain mass from branches; TGMS_thousand-grain mass from stems; PGB_grain production from branches in \%; SCWB_sequential climatological water balance; PCA_principal component analysis

\section{Introduction}

In the last decade, there have been significant changes in Brazilian soybean production, such as morphological and physiological changes of cultivars, increasing grain yield expectations, anticipating sowing dates to reduce the incidence of diseases and pests, or even to grow corn in succession. This leads to a research updating towards plant spatial arrangement, aiming to increase grain yield and crop profitability (Balbinot Junior et al., 2015a; Werner et al., 2016). Hence, alternative spatial arrangements such as narrow row spacing ( 0.20 to $0.30 \mathrm{~m}$ ) (Balbinot Junior et al., $2015 \mathrm{~b}$ ) and crossed rows have been studied, in which half of the seeds are sown in one direction and the other half to the transverse direction (Balbinot Junior et al., 2015a). Also, twin rows consist of sowing parallel rows alternating spacing, one large and one narrow (Duarte et al., 2016).

The spatial arrangement of soybean plants can be altered by sowing rate, which modifies intraspecific competition for water, light, and nutrients, influencing plant growth, canopy architecture, phytosanitary management, and grain yield (Procópio et al., 2013; Ferreira et al., 2016; Werner et al., 2016). Studies have demonstrated the high phenotypic plasticity of soybean, modifying growth and yield components as a function of the number of individuals per area. This trait helps maintaining a constant productivity in a wide range of plant densities (Rambo et al., 2004; Lee et al., 2008; Board and Kahlon, 2013; Procópio et al., 2013; De Luca and Hungria, 2014; Suhre et al., 2014; Moreira et al., 2015; Petter et al., 2016).

In Brazil, most of the studies on the phenotypic plasticity of soybean have used cultivars with determinate growth type and vigorous vegetative growth (Rambo et al., 2004). However, the majority of soybean cultivars released in the last decade have an indeterminate growth type, and lower branching and vegetative growth (Procópio et al., 2013; Zanon et al., 2015; Werner et al., 2016). Recent studies have shown that despite the morphophysiological changes, currently used cultivars present a high plasticity; hence, yield per area varies little with significant alterations in plant density and row spacing (Balbinot Junior et al., 2016; Petter et al., 2016).

Soybeans can compensate a lower density by emitting large amounts of branches or increasing branch and stem growth (Ferreira et al., 2016). However, there is a lack of information on the contribution of branch number per plant, 
grain production per branch, yield components separately evaluated from branches and stems on crop phenotypic plasticity, mainly for modern cultivars. Thus, this research was based on the following scientific questions: What are the most contributing variables related to soybean branches or stems to grain production per plant? Does it vary with row spacing?

Given the above, the objective of this study was to evaluate the contribution of the branch and soybean stem components to grain production per plant at different plant spatial arrangements using two cultivars with indeterminate growth type.

\section{Results and Discussion}

\section{Stepwise regression}

In both cropping seasons (2013/14 and 2014/15), water availability during vegetative growth was adequate but with a few water deficit events during the grain-filling period (Figure 2). However, in the 2013/14, the duration of the water deficit was higher, which limited the grain yield. The stepwise regression analysis indicated the number of pods per plant from branches (NPPLB) as the variable with the highest predictive capacity for grain production per plant (PROD) in four spatial arrangements (Tables 1 and 2, and Figures 3 and 4). In all situations, NPPLB was able to explain more than $82 \%$ of the variation in PROD.

Besides NPPLB, the adjusted coefficient of determination $\left(R^{2}\right)$ was increased with the insertion of number of pods per plant from stems (NPPLS), thousand-grain mass from stems (TGMS), and number of grains per pod from branches (NGPB), demonstrating a relevant grain production in stems at all row spacing arrangements. In this sense, for both cropping seasons and the four row spacing, grain yield variations in stems contributed to the phenotypic plasticity of soybeans. The number of branches per plant (NBPL) was not selected in the stepwise model for PROD prediction, except for twin row spacing in the 2014/15 cropping season. Soybeans can produce a large number of branches, but with small sizes and low grain yield, or even unproductive ones (Balbinot Junior et al., 2015a). Generally, one of the main variables for phenotypic plasticity evaluations of a cultivar is NBPL (Werner et al., 2016). Contrarily, this research clearly indicates this variable as less relevant than NPPLB.

Based on the angular coefficients of the adjusted models, PROD increase rate was $0.233 \mathrm{~g} \mathrm{plant}^{-1}$ due to the increment of one pod per plant from branches for the four spatial sets in the 2013/14 cropping season (Figure 3). In the 2014/15 cropping season, it was 0.426 (Figure 4). This result might have occurred because of a deeper drought during the $2013 / 14$ in the grain filling phase (Figure 2), reducing the effect of a higher NPPLB on production per plant. Therefore, under better conditions (2014/15), soybeans were more able to compensate the lower plant densities by increasing the grain production per plant. Similarly, De Bruin and Pedersen (2008) also observed soybean higher capacity to increase grain yield per plant at low densities when water was available during the crop development cycle. Thus, we may assume that under favorable environments, soybeansowing density can be reduced without changing grain yield; however, with a substantial decrease in cost of seeds as discussed by Thompson et al. (2015).

\section{Principal component analysis (PCA)}

Through principal component analysis (PCA), NPPLB, NPPLS, NBPL, and grain production from branches (PGB) showed to be the variables most associated with PROD (Figures 5 and $6)$, once vectors were long and close to PROD. In contrast, NGPB and number of grains per pod from stems (NGPS) had small contribution, being far from the PROD. In general, the vector of TGMS and thousand-grain mass from branches (TGMB) were opposite to PROD, except for twin row spacing in the $2013 / 14$ cropping season. Ferreira et al. (2016) verified a significant reduction in thousand-grain mass by decreased sowing densities. They also noted an increase in the percentage of grains from branches, which might have decreased demanded force to stems. These results are in agreement with those of Bellaloui et al. (2015), which showed decreases in protein, sucrose, glucose, raffinose, boron, and phosphorus contents in grains as a function of sowing density reductions. Kumagai et al. (2015) also found that number of pods per plant (stems plus branches) as the main indicator of phenotypic plasticity in soybean cultivars. In this context, we could verify that the mechanisms of phenotypic plasticity in modern cultivars with indeterminate growth type, compact plant architecture and early cycle were the same for the four row spacing and both cropping seasons, even presenting different water availability during crop development cycle.

\section{Materials and Methods}

\section{Experimental area}

Four experiments were conducted in Londrina, Paraná, Brazil (2311'S, 5111' $W$ and $620 \mathrm{~m}$ above sea level, CfaKöpenGeiger climate, Rhodic Eutrudox soil type, USDA) during the 2013/14 and 2014/15 cropping season. Each experiment was carried out with one of the following spacing between the rows: Experiment 1= $0.2 \mathrm{~m}$ (narrow row); Experiment 2=0.5 $\mathrm{m}$ (traditional); Experiment $3=0.5 \mathrm{~m}$ (crossed rows) and Experiment $4=0.2 / 0.8 \mathrm{~m}$ (twin rows) (Figure 1). The soil of the experimental area had the following attributes in the 0$20 \mathrm{~cm}$ layer: $21.4 \mathrm{~g} \mathrm{dm}^{-3}$ of organic carbon, $4.9 \mathrm{pH}$ in $\mathrm{CaCl}_{2}$, $8.6 \mathrm{mg} \mathrm{dm}^{-3}$ of $\mathrm{P}$ (Mehlich 1), $0.55 \mathrm{cmolc} \mathrm{dm}^{-3}$ exchangeable

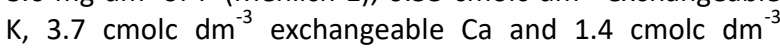
exchangeable $\mathrm{Mg}$. The sequential climatological water balance (SCWB) of Thornthwaite and Mather (1955) at the two cropping season is presented in Figure 2. For SCWB determination, the reference evapotranspiration (ETo) was calculated during the experimental period by PenmanMonteith and transformed into soybean evapotranspiration $(E T C=E T o \times K c)$. The available soil water capacity for the SCWB calculation was $75 \mathrm{~mm}$ and the adopted Kc was 0.35 .

\section{Treatments and experimental design}

The experimental design was a randomized complete block with three replicates. In each experiment, we evaluated two soybean cultivars (BMX Potência RR and BRS 359 RR) and three sowing rates $\left(150,300\right.$, and 450 thousand seeds $\left.\mathrm{ha}^{-1}\right)$. Both BMX Potência RR and BRS 359 RR presented an indeterminate growth type and relative maturity group 6.7 and 6.0 , respectively. The recommended sowing density is 
Table 1. Modeling and adjusted coefficients of determination $\left(R_{a}^{2}\right)$ calculated by stepwise analysis, considering grain yield per plant of soybean (g) (PROD) as a dependent variable, in four row spacing. Londrina, Paraná state, Brazil, 2013/14 cropping season.

\begin{tabular}{|c|c|}
\hline Adjusted models & $R_{a}^{2}$ \\
\hline \multicolumn{2}{|l|}{$0.20 \mathrm{~m}$ (narrow row) } \\
\hline PROD $=4.19 * *+0.204$ NPPLB $* *$ & 0.847 \\
\hline $\mathrm{PROD}=-8.56^{* *}+0.193 \mathrm{NPPLB}^{* *}+5.698 \mathrm{NGPB}{ }^{* *}$ & 0.933 \\
\hline$P R O D=-13.51^{* *}+0.202 \mathrm{NPPLB}^{* *}+5.399 \mathrm{NGPB}^{* *}+5.399 \mathrm{TGMS}^{* *}$ & 0.955 \\
\hline \multicolumn{2}{|l|}{$0.50 \mathrm{~m}$ (traditional) } \\
\hline $\mathrm{PROD}=3.88^{* *}+0.235$ NPPLB** & 0.893 \\
\hline PROD $=0.116^{*}+0.206$ NPPLB**+0.189 NPPLS** & 0.949 \\
\hline PROD $=-3.80 *+0.210$ NPPLB $* *+0.236$ NPPLS $^{* *}+1.303 \mathrm{NGPB}^{* *}$ & 0.966 \\
\hline \multicolumn{2}{|l|}{$0.50 \mathrm{~m}$ (crossed rows) } \\
\hline PROD $=3.66^{* *}+0.237 N^{\prime} P$ LB $* *$ & 0.828 \\
\hline PROD $=-0.529 n s+0.205$ NPPLB $^{* *}+0.223 N^{*} P L S^{* *}$ & 0.971 \\
\hline $\mathrm{PROD}=-3.51^{*}+0.200 \mathrm{NPPLB}^{* *}+0.234 \mathrm{NPPLS}^{* *}+1.271 \mathrm{NGPB} *$ & 0.977 \\
\hline \multicolumn{2}{|l|}{$(0.20 / 0.80 \mathrm{~m})$ (twin rows) } \\
\hline $\mathrm{PROD}=2.93^{* *}+0.257 \mathrm{NPPLB} * *$ & 0.921 \\
\hline$P R O D=0.291 \mathrm{~ns}+0.227 \mathrm{NPPLB}^{* *}+0.162 \mathrm{NPPLS}^{* *}$ & 0.947 \\
\hline PROD $=-5.21 *+0.211 \mathrm{NPPLB}^{* *}+0.172 \mathrm{NPPLS}^{* *}+0.059 \mathrm{TGMS} *$ & 0.963 \\
\hline
\end{tabular}

NPPLB $=$ Number of pods per plant from branches, NGPB = Number of grains per pod from branches, NPPLS= Number of pods per plant from $s$ tems, TGMS= Thousand grain mass from stems e NGPB=Number of grains per pod from branches. ${ }^{* *}$ Adjusted Coefficients of Determination $\left(R_{a}^{2}\right)(p \leq 0.01)$ and $*(p \leq 0.05)$; ns Non-significant coefficients.

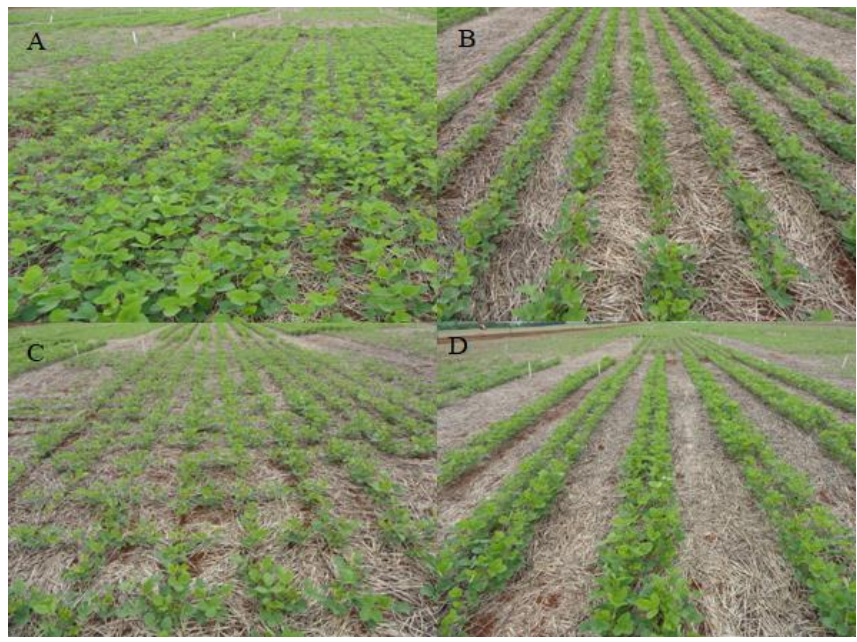

Fig 1. Row spacing evaluated: A: $0.2 \mathrm{~m}$ (narrow row); B: $0.5 \mathrm{~m}$ (traditional); C: $0.5 \mathrm{~m}$ (crossed rows) and D: $0.2 / 0.8 \mathrm{~m}$ (twin rows). Londrina, Paraná state, Brazil.

Table 2.Modeling and adjusted coefficients of determination $\left(R_{a}^{2}\right)$ calculated by stepwise analysis, considering grain yield per plant of soybean (g) (PROD) as a dependent variable, in four row spacing. Londrina, Paraná state, Brazil, 2014/15 cropping season.

\begin{tabular}{|c|c|}
\hline Adjusted models & $R_{a}^{2}$ \\
\hline \multicolumn{2}{|l|}{$0.20 \mathrm{~m}$ (narrow row) } \\
\hline PROD $=6.39 * *+0.455$ NPPLB** & 0.875 \\
\hline PROD $=4.36^{* *+0.357 ~ N P P L B * *+0.131 ~ N P P L S ~ n s ~}$ & 0.888 \\
\hline PROD $=-12.66^{* *}+0.296 \mathrm{NPPLB}^{* *}+0.376 \mathrm{NPPLS}^{* *}+0.080 \mathrm{TGMS}^{* *}$ & 0.945 \\
\hline \multicolumn{2}{|l|}{$0.50 \mathrm{~m}$ (traditional) } \\
\hline $\mathrm{PROD}=6.59 * *+0.423 \mathrm{NPPLB} * *$ & 0.867 \\
\hline$P R O D=-0.57 n s+0.432$ NPPLB**+0.045TGMS* & 0.900 \\
\hline PROD $=-14.84^{* *+0}+333 \mathrm{NPPLB}^{* *}+0.387 \mathrm{NPPLS}^{* *}+0.095 \mathrm{TGMS}^{* *}$ & 0.952 \\
\hline \multicolumn{2}{|l|}{$0.50 \mathrm{~m}$ (crossed rows) } \\
\hline $\mathrm{PROD}=7.85^{* *}+0.417 \mathrm{NPPLB} * *$ & 0.877 \\
\hline PROD $=0.297 n s+0.441 \mathrm{NPPLB}^{* *}+0.035 \mathrm{TGMS}^{* *}$ & 0.927 \\
\hline $\begin{array}{l}\text { PROD }=-2.40 \mathrm{~ns}+0.397 \mathrm{NPPLB} * *+0.159 \mathrm{NPPLS}^{*}+0.043 \mathrm{TMS}^{* *} \\
(0.20 / 0.80 \mathrm{~m}) \text { (twin rows) }\end{array}$ & 0.946 \\
\hline PROD $=6.25^{* *}+0.409 N_{P P L B}^{* *}$ & 0.885 \\
\hline $\mathrm{PROD}=5.28^{* *}+1.04 \mathrm{NPPLB}^{*}+0.298 \mathrm{NBP} * *$ & 0.911 \\
\hline
\end{tabular}

NPPLB $=$ Number of pods per plant from branches, NPPLS= Number of pods per plant from stems, TGMS= Thousand grain mass from stemsandNBP $=$ Number of branches per plant. ** Adjusted Coefficients of Determination $\left(R_{a}^{2}\right)(p \leq 0.01)$ and $*(p \leq 0.05)$; ns Non-significant coefficients. 

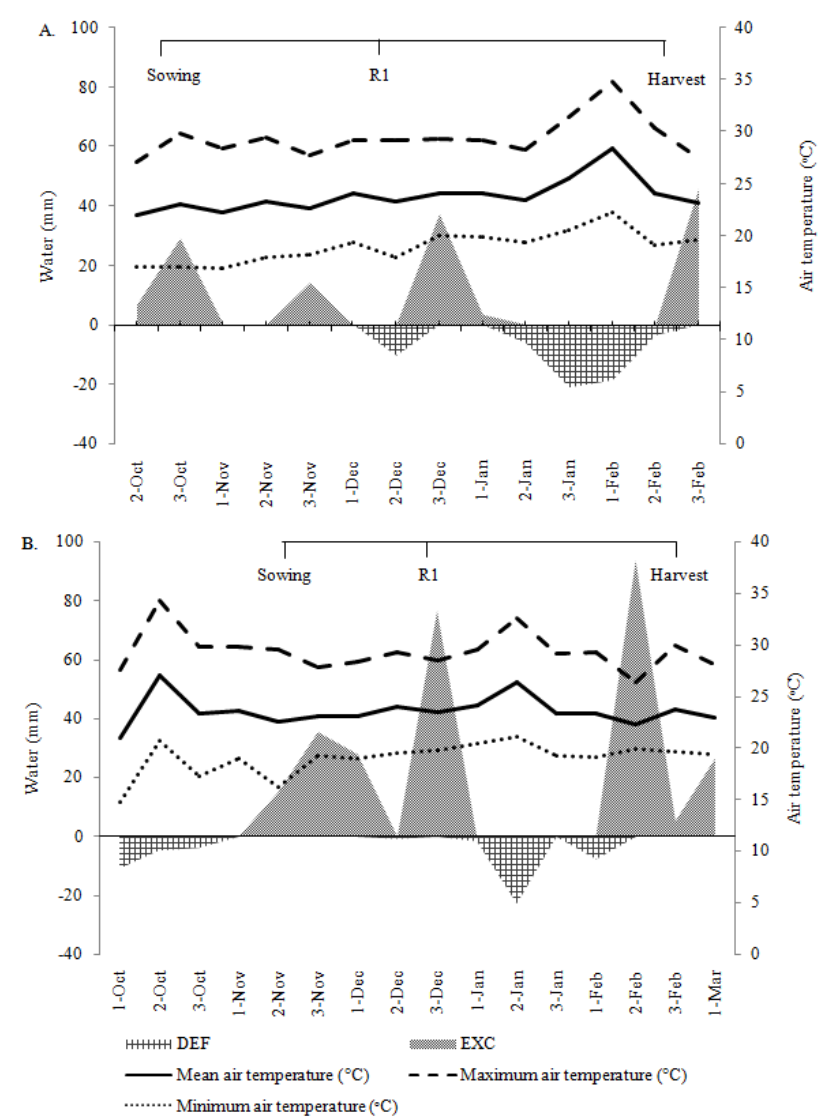

Fig 2. Sequential climatological water balance $(\mathrm{mm})$ of Thornthwaite and Mather during the soybean development cycle. Londrina, Paraná state, Brazil, 2013/14 (A) and 2014/15 (B) cropping seasons.
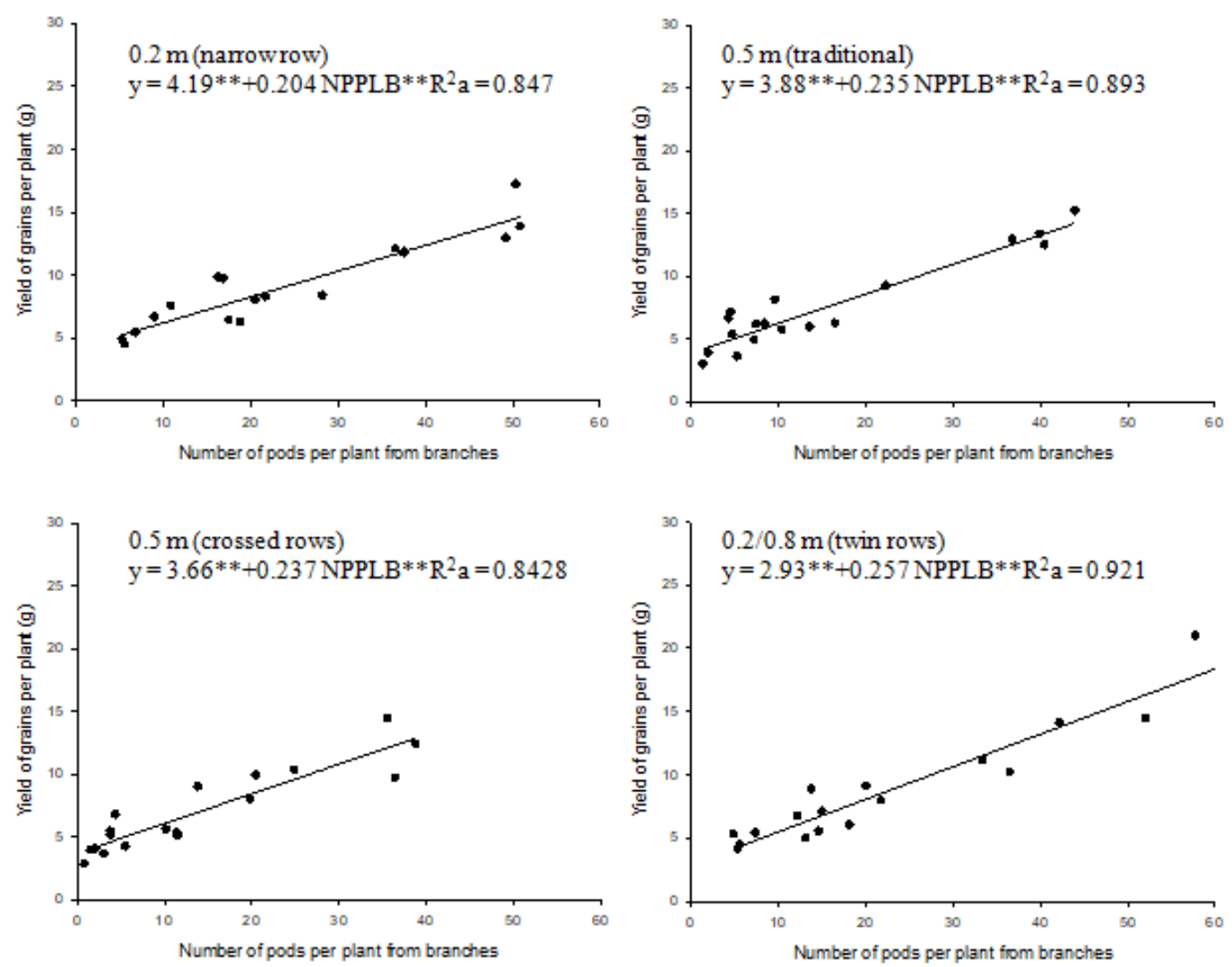

Fig 3. Relationship between the number of pods per plant from branches and the grain yield per plant in four row spacing. Londrina, Paraná state, Brazil, 2013/14 cropping season. 

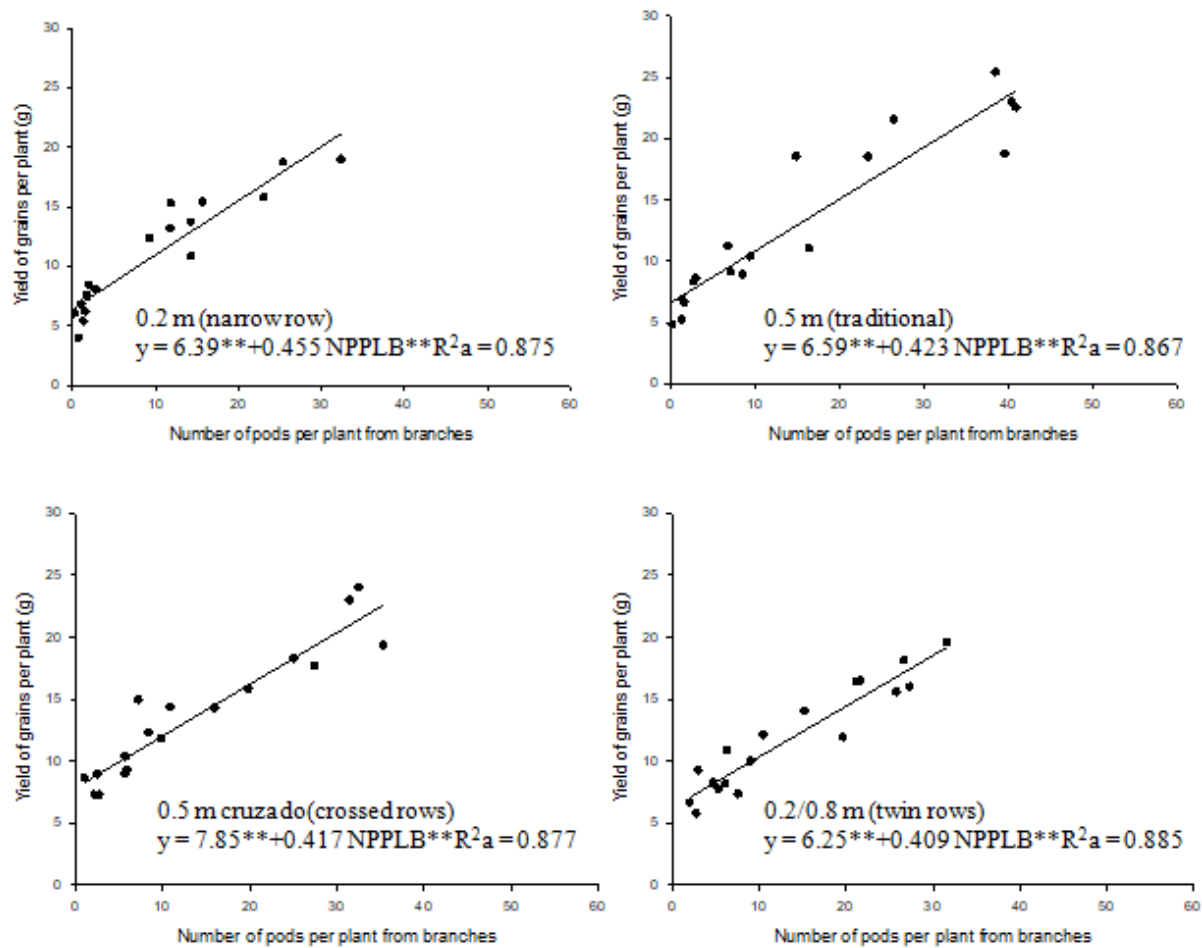

Fig 4. Relationship between the number of pods per plant from branches and the grain yield per plant in four row spacing. Londrina, Paraná state, Brazil, 2014/15 cropping season.
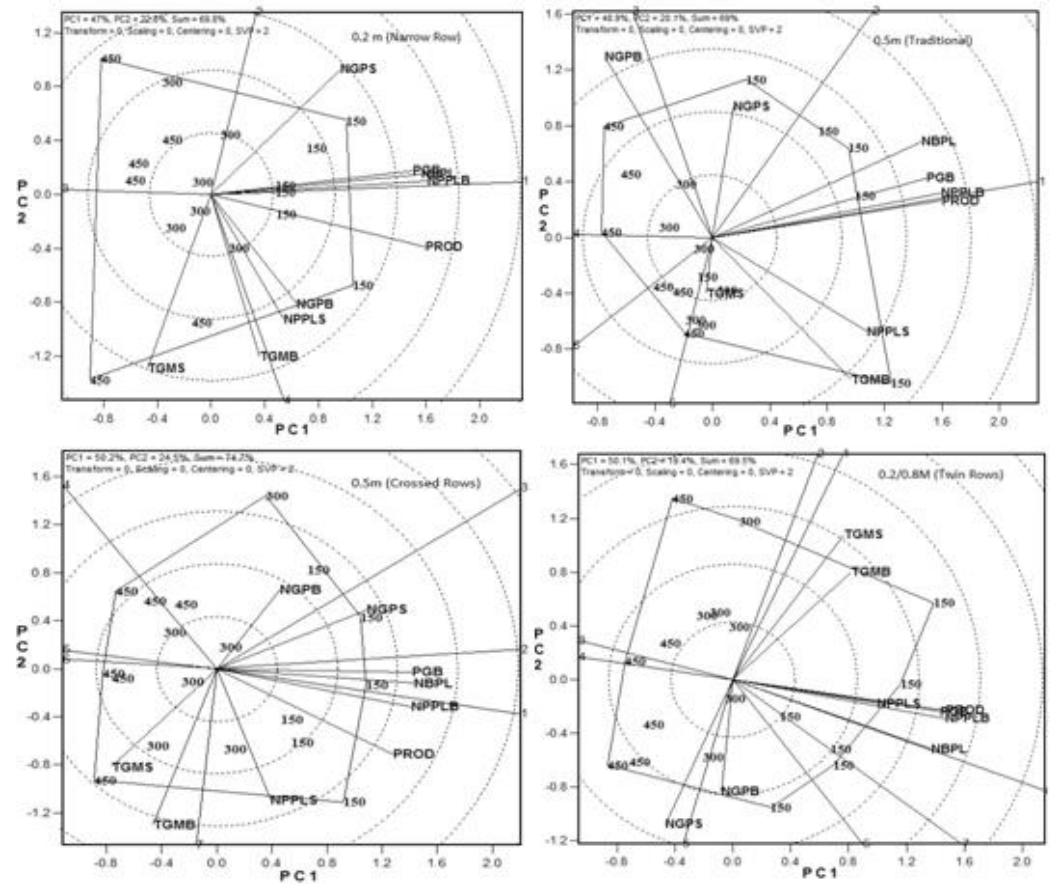

Fig 5. GGE biplot vectors in four row spacing. The independent variables is the number of branches per plant (NBP), number of pods per plant from branches (NPPLB), number of pods per plant from stem (NPPLS), number of grains per pod from branches (NGPB), number of grains per pod from stems (NGPS), thousand-grain mass from branches (TGMB), thousand-grain mass from stems (TGMS) and percentage of grain yield from branches (PGB) and the dependent variable is the production of grains per plant (PROD). The numbers in the figure refer to the evaluated densities: 150, 300 and 450 plants ha ${ }^{-1}$. Londrina, Paraná state, Brazil, 2013/14 cropping season. 

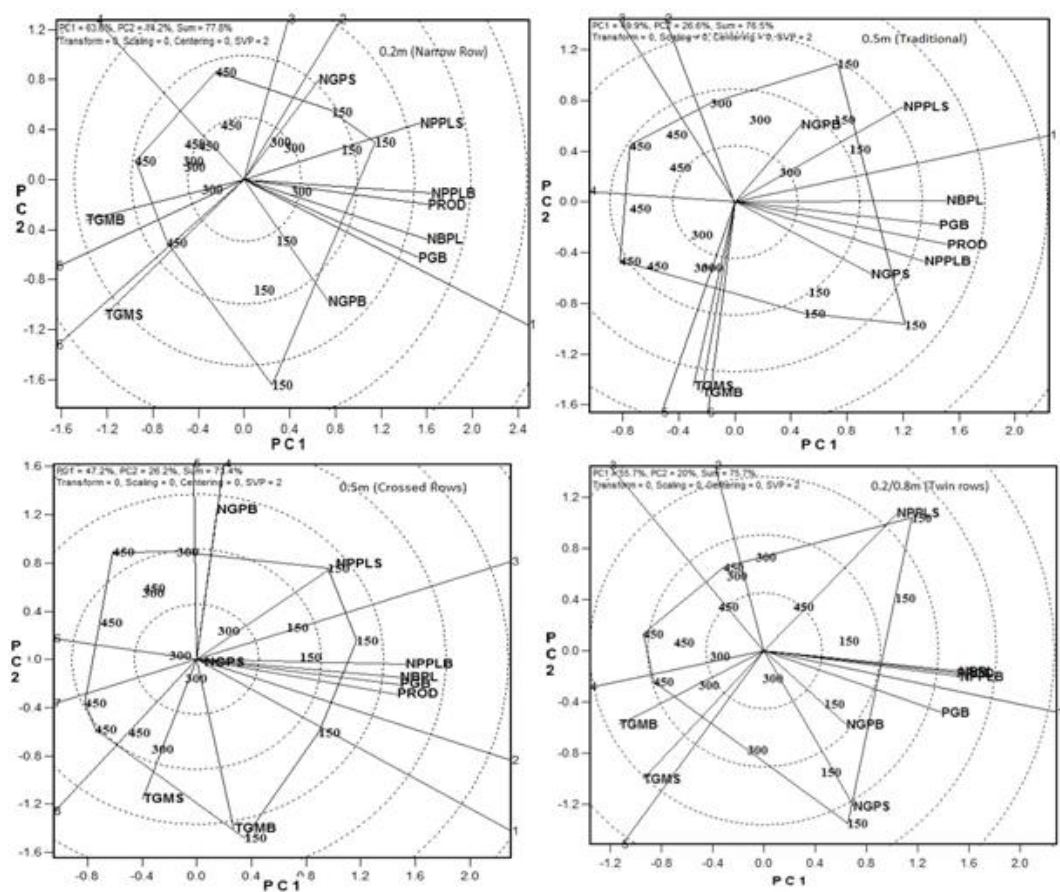

Fig 6. GGE biplot vectors in four row spacing. The independent variables is the number of branches per plant (NBP), number of pods per plant from branches (NPPLB), number of pods per plant from stem (NPPLS), number of grains per pod from branches (NGPB), number of grains per pod from stems (NGPS), thousand-grain mass from branches (TGMB), thousand-grain mass from stems (TGMS) and percentage of grain yield from branches (PGB) and the dependent variable is the production of grains per plant (PROD).The numbers in the figure refer to the evaluated densities: 150, 300 and 450 plants ha ${ }^{-1}$. Londrina, Paraná state, Brazil, 2014/15 cropping season.

between 265,000 to 310,000 plants $\mathrm{ha}^{-1}$ for BMX RR Potência, and from 220,000 to $265,000 \mathrm{ha}^{-1}$ plants for BRS 359 RR. The plots measured $10 \mathrm{~m}$ in length and $5 \mathrm{~m}$ in width, totaling $50 \mathrm{~m}^{2}$. The useful area used was $24 \mathrm{~m}^{2}(8 \mathrm{~m}$ long and $3 \mathrm{~m}$ wide). The two seeding dates were October 23, 2013; and November 11, 2014. On the sowing day, seeds were treated with Vitavax-Thiran $200 \mathrm{SC}^{\circledR}$ (Carboxin + Thiram - $150 \mathrm{~mL} 50 \mathrm{~kg}^{-1}$ of seed) and Gelfix $5^{\circledR}$ liquid inoculant (100 $\mathrm{ML} 50 \mathrm{~kg}^{-1}$ of seeds). Soil fertilization consisted of $125 \mathrm{~kg} \mathrm{ha}^{-1}$ triple superphosphate $\left(41 \%\right.$ of $\left.\mathrm{P}_{2} \mathrm{O}_{5}\right)$ and $250 \mathrm{~kg} \mathrm{ha}^{-1}$ potassium chloride $\left(50 \%\right.$ of $\left.\mathrm{K}_{2} \mathrm{O}\right)$ applied ten days prior to sowing.

\section{Traits measured}

At harvest, 20 plants per plot were sampled for the following evaluations: grain production per plant (PROD), a dependent variable representing soybean phenotypic plasticity, number of branches per plant (NBPL), number of pods per plant from branches (NPPLB) and from stems (NPPLS), number of grains per pod from branches (NGPB) and from stems (NGPS), thousand-grain mass from branches (TGMB) and from stems (TGMS), and grain production from branches in \% (PGB).

\section{Statistical analysis}

Normality, independence of residues, variance homogeneity of treatments, and non-additivity of the model were verified. A stepwise regression analysis was performed to determine models with a higher predictive capacity for production per plant. In addition, Pearson correlation analysis was performed among the evaluated variables. The regression and correlation analyses were performed through the SAS 9.2 software.

After detecting a significant Pearson correlation ( $p \leq 0.05)$ between the variables and standardizing them for a dimensionless scale, the most relevant independent variables were defined in the determination of production by plant, by principal component analysis (PCA), using the GGEbiplot program. The standardization helped to avoid the variables measured with the largest variances dominate the others. The polygonal biplot with concentric circles was based on the Singular Value Decomposition (SVD). By SVD, the matrix is decomposed into singular values, column eigenvectors and eigenvector lines. The singular value of the matrix is a diagonal matrix. The biplot is formed with the main component scores (CP1) in the abscissa and ordinate scores (CP2) for each treatment and each variable (Yan and Rajcan, 2002) and the model may be expressed by the following equation:

$\frac{T_{i j}-\bar{T}_{j}}{s_{j}}=\lambda_{1} \phi_{i 1} \tau_{j 1}+\lambda_{2} \phi_{k 2} \tau_{j 2}+\varepsilon_{i j}$

$T_{i j}$ mean value of the densities i for the variable $\mathrm{j}$,

$\bar{T}_{j}$ meanvalue of the variable $\mathrm{j}$ on the general mean of the densities,

$\lambda_{1} e \lambda_{2}$ singular values for the components CP1 and CP2, $s_{j}$ standard deviation of the variables $\mathrm{j}$ between the mean densities, $\phi_{i 1}$ e $\phi_{i 2}$ scores of the main components CP1 and CP2, respectively,

for the 
density i, $\tau_{j 1}$ e $\tau_{j 2}$ scores $\mathrm{CP} 1$ and $\mathrm{CP} 2$, associated with variables $\mathrm{j}, \varepsilon_{i j}$ model residue associated with densities $\mathrm{i}$ in variable $\mathrm{j}$.

\section{Conclusion}

The number of pods per plant from branches was the most determinant variable for the phenotypic plasticity in modern cultivars of soybeans, with indeterminate growth habit regardless of the spatial arrangement. The principal component analysis indicated the number of pods per plant from branches and stems, the number of branches per plant, and the percentage of grain production from branches as variables strongly associated with the phenotypic plasticity of modern cultivars of soybeans. The number of grains per pod and the thousand-grain mass from branches and stems had no significant contribution to the plasticity of soybeans, regardless of the spatial arrangement.

\section{Acknowledgements}

Thanks to Conselho Nacional de Desenvolvimento Científico e Tecnológico (CNPq), for granting the first author with a fellowship of productivity for technological development and innovative extension.

\section{References}

Balbinot Junior AA, Procópio SO, Costa JM, Kosinski CL, Panison F, Debiasi H, Franchini JC (2015a) Espaçamento reduzido e plantio cruzado associados a diferentes densidades de plantas de soja. Semin-Cienc Agrar. 36:2977-2986.

Balbinot Junior AA, Procópio SO, Debiasi H, FranchiniJC, Panison F (2015b) Semeadura cruzada em cultivares de soja com tipo de crescimento determinado. Semin-Cienc Agrar. 36:1215-1226.

Balbinot Junior AA, Procópio SO, Neumaier N, Ferreira AS, Werner F, Debiasi H, Franchini JC (2016) Semeadura cruzada, espaçamento entre fileiras e densidade de semeadura influenciando o crescimento e a produtividade de duas cultivares de soja. Rev Cienc Agrovet. 15:83-93.

Bellaloui N, Bruns HA, Abbas HK, Mengistu A, Fisher DK, Reddy KN (2015) Effects of Row-Type, Row-Spacing, Seeding Rate, Soil-Type, and Cultivar differences on Soybean Seed Nutrition under US Mississippi Delta Conditions. Plos One. 10:1-23.

Board JE, Kahlon CS (2013) Morphological responses to low plant population differ between soybean genotypes. Crop Sci. 53:1109-1119.

De Bruin J L, Pedersen P (2008) Effect of row spacing and seeding rate on soybean yield. Agron J. 100:704-710.

De Luca MJ, Hungria M (2014) Plant densities and modulation of symbiotic nitrogen fixation in soybean. Sci Agric. 71:181-187.
Duarte TC, Cruz SCS, Soares GF, Sena Júnior DG, Machado CG (2016) Spatial arrangements and fertilizer doses on soybean yield and its components. Rev Bras Eng Agr Amb. 20:960-964.

Ferreira AS, Balbinot Junior AA, Werner F, Zucareli C, Franchini JC, Debiasi H (2016) Plant density and mineral nitrogen fertilization influencing yield, yield components and concentration of oil and protein in soybean grains. Bragantia. 75:362-370.

Kumagai E, Aoki N, Masuya Y, Shimono H (2015) Phenotypic plasticity conditions the response of soybean seed yield to elevated atmospheric $\mathrm{CO}_{2}$ concentration. Plant Physiol. 169:2021-2029.

Lee CD, Egli DB, Tekrony DM (2008) Soybean response to plant population at early and late planting dates in the Mid-South. Agron J. 100:971-976.

Moreira A, Moraes LAC, Schroth G, Mandarino JMG (2015) Effect of Nitrogen, Row Spacing, and Plant Density on Yield, Yield Components, and Plant Physiology in SoybeanWheat Intercropping. Agron J. 107:2162-2170.

Petter FA, Silva JA, Zuffo AM, Andrade FR, Pacheco LP, Almeida FA (2016) Elevada densidade de semeadura aumenta a produtividade da soja? Respostas da radiação fotossinteticamente ativa. Bragantia. 75:173-183.

Procópio SO, Balbinot Junior AA, Debiasi H, Franchini JC, Panison F (2013) Plantio cruzado na cultura da soja utilizando uma cultivar de hábito de crescimento indeterminado. Amazon J Agric Env Sci. 56:319-325.

Rambo L, Costa JA, Pires JLF, Parcianello G, Ferreira FG (2004) Estimativa do potencial de rendimento por estrato do dossel da soja, em diferentes arranjos de plantas. Cienc Rural. 34:33-40.

Suhre JJ, Weidenbenner NH, Rowntree SC, Wilson EW, Naeve SL, Conley SP, Davis VM (2014) Soybean yield partitioning changes revealed by genetic gain and seeding rate interactions. Agron J. 106:1631-1642.

Thompson NM, Larson JA, Lambert DM, Roberts RK, Mengistu A, Bellaloui N, Walker ER (2015) Mid-South Soybean Yield and Net Return as Affected by Plant Population and Row Spacing. Agron J. 107:979-989.

Thornthwaite CW, Mather JR (1955) The water balance. Centerton, NJ: Drexel Institute of Technology - Laboratory of Climatology.

Yan WK, Rajcan I (2002) Biplot analysis of test sites and trait relations of soybean in Ontario. Crop Sci. 42:11-20.

Werner F, Balbinot Junior AA, Ferreira AS, Aguiar e Silva MA, Debiasi H, Franchini JC (2016) Soybean growth affected by seeding rate and mineral nitrogen. Rev Bras Eng Agr Amb. 20:734-738.

Zanon AJ, Streck NA, Richter GL, Becker CC, Rocha TSM, Cera JC,Weber PS (2015) Contribuição das ramificações e a evolução do índice de área foliar em cultivares modernas de soja. Bragantia.74:279-290. 